\title{
Enterprises Short-Term Financing Management
}

\author{
Zhang Tiantian*, Hanping Hou, Jianliang Yang \\ School of Economics and Management \\ Beijing Jiaotong University \\ Beijing, China \\ 16120596@bjtu.edu.cn
}

\author{
Xue Li, Yue Wang \\ Assistant Engineer \\ Space star technology co., LTD \\ Beijing, China \\ Lixueb2141@163.com
}

\begin{abstract}
As modern enterprises, financing is the perpetual theme of their living and development. Therefore, each enterprise needs to achieve its resource allocation and economic activities through financial channels. To a certain extent, financing management decides the success of business operations. Besides, short-term financing management is one of the most important financing decisions in the management. In this paper, according to the internal and external causes of short-term financing risks, analysis and study are aimed at the classification, mode, type and different solutions of short-term financing of enterprises. In order to avoid the waste of manpower, material resources, money and time in the process of financing, this study is available for providing reference to optimize short-term financing for efficient organization and risk reduction.
\end{abstract}

Keywords-Short-term; Financing management; Current liabilities; Current liability

\section{INTRODUCTION}

Short-term financing refers to the financing of the short-term liquidity needs of the enterprise[1]. Obtaining current liabilities is a frequent type of short-term financing so short-term financing is also known as current liabilities financing or short-term debt financing. With the establishment of market economic system, enterprises as independent generators and producers take on important responsibilities of modern corporate finance to find the most economic and rational way of financing and its management for production and operation, which is also one of the essential elements for financial managers. Besides, short-term financing management is one of the most important financing decisions in the management.

\section{The ClassificAtion OF SHORT-TERm FinANCING}

Short-term financing can be classified into different types, depending on what criteria attempt to follow. The following is a description of the most common types:

\section{A. According to whether the amount payable is determined}

There are short-term liabilities certain amount payable and uncertain amount payable. Short-term liabilities with certain amount payable such as short-term borrowings, bills payable and accounts payable should comply with contract or legal requirements. Short-term liabilities with uncertain amount payable can be determined at a specific time with analysis of production and operation of the company or can be estimated by amount payable, such as tax payable and profit payable[2].

\section{B. According to the formation of short-term liabilities}

There are natural short-term liabilities and temporary short-term liabilities. Natural short-term liabilities such as commercial credit, tax payable and wage payable are naturally formed in the company's daily business activities without formal arrangements and settlement procedures. Temporary short-term liabilities such as short-term bank loans are contingent funds required by the financial staff based on the analysis of short-term funding needs.

\section{THE WAY OF SHORT-TERM FINANCING}

\section{A. Commercial credit}

Commercial credit is the borrowing relationship between enterprises in the course of commodity transaction or after the payment of deferred payment. It is the source of funds formed by mutual credit between enterprises in the course of normal business transactions. In other words, the seller can provide commercial credit to the buyer without the need for formal consultations and without the buyer's formal instrument. Commercial credit financing is established on the basis of the enterprise's financial credibility. Maintaining a good business financial reputation is undoubtedly favorable for the short-term corporate funds.

\section{B. Short-term loan}

Short-term borrowings refer to borrowings borrowed by banks and other non-bank financial institutions for a period of one year. Short-term borrowing is a very flexible way of financing. Companies can apply for short-term loans to the bank with right qualifications. When using this financing method, special attention should be paid to the corporate asset liquidity. The amount and time of the recovered funds of the enterprise investment project shall be in accordance with the investment conditions[3].

\section{Short-term bond}

Short-term financing bonds are a short-term unsecured promissory note issued by large industrial and commercial enterprises. Short-term financing bonds have lower financing costs and raise more money. Enterprises can issue short-term financing bills to improve the company's reputation and credibility. The issuance of short-term financing bonds will face greater risk and lack flexibility with more strict requirements. 


\section{The Type of Short-Term FinANCing Policy}

\section{A. Fit-based financing policy}

Fit-based financing policy is characterized by the fact that temporary liquid assets are financed by short-term liabilities to meet their funding needs. Long-term assets such as permanent current assets and fixed assets are financed by long-term debt and equity financing to meet capital requirements. But this strategy is difficult to realize real-world applications because of its too idealistic hypothesis.

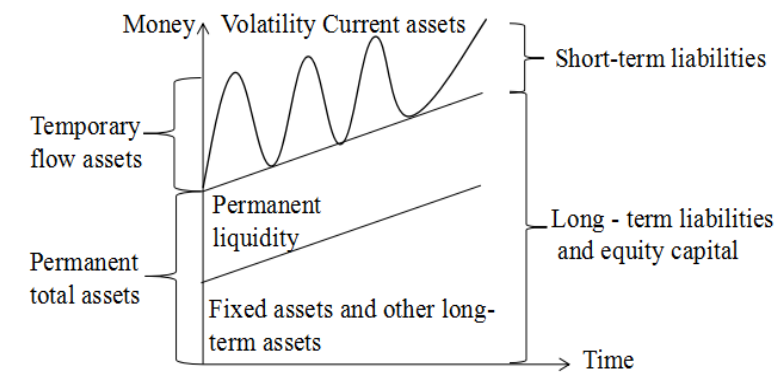

Fig. 1. Fit-based financing policy

In the case of "Fit-based financing" (Figure 1), funds required for permanent total assets, including long-term assets such as permanent current assets and fixed assets, are usually provided by long-term liabilities and equity capital. If a enterprise chooses a cooperative financing policy, the pressure of the enterprise to pay the debt is greater than the steady financing policy while less than the radical financing policy. According to the analysis of merits of the three, Fit-based financing policies are between the radical financing policy and the robust financing policy.

\section{B. Radical financing policy}

The characteristics of the radical financing policy are: short-term liabilities need to meet some of the permanent liquidity as well as temporary liquidity of the financial needs. In some specific cases, all short-term assets are provided by short-term liabilities. It is a high-yield and high-risk financing policy.

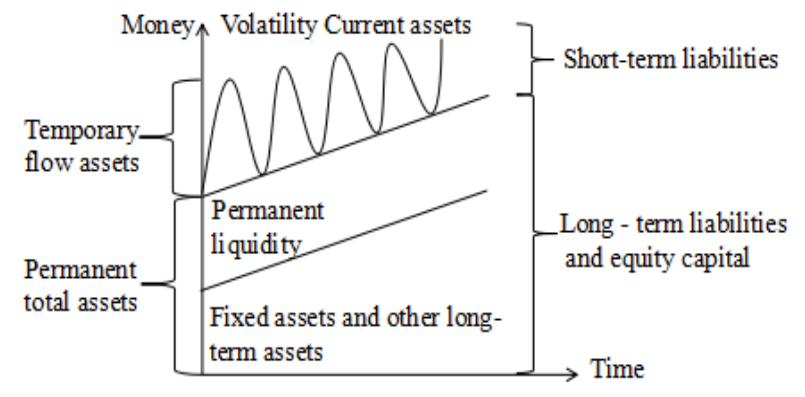

Fig. 2. Radical financing policy.

In the case of "Radical financing" (Figure 2), some of the permanent liquid assets and all temporary liquid assets required by the enterprise are provided by short-term liabilities, while the other part of financing for long-term assets such as permanent current assets and fixed assets are provided by long-term liabilities and equity capital. Under the aggressive financing model, the short-term liabilities are not only to meet temporary liquidity needs but also permanent liquidity needs for funds.

\section{Robust financing policy}

The robust financing policy is characterized by the fact that short-term liabilities only meet the capital requirements of some of the temporary current assets, and that other temporary liquidity assets and permanent aggregate assets are provided by long-term liabilities and equity capital. It is a low-risk, low-yield financing policy.

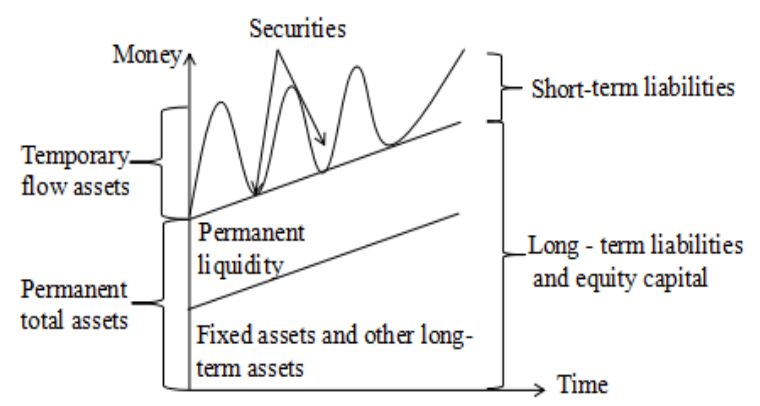

Fig. 3. Robust financing policy.

In the case of "Robust financing"(Figure 3), companies can use short-term debt financing to obtain funds when they need to cope with the peak demand for funds. This kind of financing policy is faced with very low risk because of little short-term debt financing. On the other hand, more long-term liabilities and equity capital which does not have the tax effect lead to higher cost.

\section{In VIEW OF THE SHORT-TERM FinANCING RiSK SOLUTIONS}

\section{A. Solution to the internal causes of short - term financing risks}

1) Keep the way of financing relatively stable

With the integration of globe economy and international capital flows, there are many options for short-term financing. Enterprises must make a choice, only after fully considering the advantages and disadvantages of various financing methods, can they formulate the best financing plan according to their own development needs[4]. Generally, enterprises should maintain relatively stable financing methods, which can not only enable enterprises to raise funds at a low cost, but also help maintain a good image of enterprises in the financial market.

\section{2) Strengthen enterprise financial budget management}

Budget management plays an important role in the production, operation and overall development of enterprises, which is the biggest internal control mechanism in the process of operation. Combined with the actual situation of enterprises and the overall development strategies and operational objectives, enterprises should identify the total amount of short-term funding needs and maintain a reasonable rate of assets and liabilities. Specifically, enterprises should accomplish financial budget strictly and strengthen the management of accounts receivable to interlink the financing 
time, money and transformation closely.

\section{3) Appropriate arrangements for the term of funding}

The term structure of enterprise financing includes the time of repayment of principal and interest. The investment and production demand of enterprise determines the financing period [5]. It is necessary to consider the various factors when enterprises are programming financing schemes. Improper arrangement causing concurrent maturity of several debts or excessive rely on some kinds of financing will bring financial crisis to the enterprise. Of course, it is difficult for us to take consideration of various risks and benefits of enterprises, but at least we should weigh the risk of debt and the cost of capital size and then choose proper period of combination to meet the enterprise's own actual needs.

\section{4) Moderate debt management}

Enterprises should plan the debt management "degree", as far as possible to avoid risks. First of all, the scale of business should be considered from the scale of business, usually the larger the scale of a business, its ability to resist risk is stronger. On the contrary, if the business scale is small, then its ability to resist risks is relatively weak, if the blind increase in debt, will increase the financial risk to the enterprise. Second, the business income should be considered, if the business income is relatively large and relatively stable, then the solvency of enterprises will be relatively enhanced. if the business income is not stable, its solvency is relatively weak. Finally, take into account the profitability of enterprises, a strong profitability of enterprises tend to have a better reputation, its solvency and financing capacity are relatively strong, reducing the business risk[6].

\section{B. Solution to the external causes of short - term financing risks}

\section{1) Strengthen enterprise management}

Strengthen the management can avoid the occurrence of operational risks effectively. Firstly, improving enterprise's technical management and quality management is good to improve product quality and grade and increase the market competitiveness. Secondly, we must strengthen the financial management of enterprises, so that the capital structure of enterprises to optimize and reduce the financial pressure on enterprises. Finally, enterprises should pay attention to the cultivation and management of talent, good human resources is the driving force for enterprise development, Enterprises need to enhance the sense of responsibility and sense of belonging to employees, and strive to attract outstanding talent.

\section{2) Reasonable adjustment of asset structure}

Enterprise's various types of assets in the total assets of enterprises accounted for different proportions; virtually increase the financial risk of enterprises. For example, short-term financing requires a longer period of reimbursement of funds, requiring enterprises to have higher maturity of solvency, if the liquidity of the funds is not high; it will bring financial risks to the enterprise. Enterprises should shorten the production cycle, improve the level of production technology, improve the internal control system, and reduce the proportion of total assets in the fixed assets.
3) Optimize the production and operation links

This mainly refers to the management of enterprises to ensure the correctness of business decisions, the control of the implementation of the plan, the maturity of the enterprise debt ratio and the correct use of credit policy improve the bank-enterprise cooperation. For enterprises, strict production and operation of the operation process can make the production and operation and financial forecast closely linked to achieve the expected cash inflows on time to pay the full amount of principal and interest.

\section{4) Focus on tax policy and funding constraints}

Enterprises should always pay attention to the tax relief policies related to fund-raising business, for example, the relevant provisions of the state, some profitable enterprises in the merger of the loss of enterprises can enjoy partial tax concessions. The state's laws and regulations also have restrictions on corporate finance, which are the constraints of social conditions faced by corporate finance[7]. Therefore, companies should focus on the country's tax policy and funding constraints to reduce financing costs.

\section{CONCLUSION}

The flexibility and diversity of short-term financing attract companies to make short-term debt financing decisions, but companies should also consider the short-term financing risks. In the short-term debt, the company should consider the advantages and disadvantages of short-term liabilities recognize their own industry development cycle and development status. Companies should evaluate the optimal structure of their financing and the lowest cost, and achieve the goal of corporate financial management ultimately.

\section{ACKNOWLEDGMENT}

The writing of the essay is challenging. I am especially grateful to my tutor. The completion of this paper without the tutor's patience guidance, but also thanks to my friends and classmates, their support and encouragement make me insist on the completion of the paper. Because of the rush of time and the lack of my professional level, the whole paper must have shortcomings and errors. Your comment is appreciated.

\section{REFERENCES}

[1] Li Xiaoxia. China's SME financing research [D]. China Ocean University, 2010.(In Chinese)

[2] Jing Xin, Wang Huacheng, Liu Junyan. Financial Management [M]. Beijing: Renmin University of China Press, 2012: 325-345.(In Chinese)

[3] Zhang Man. Large iron and steel manufacturing enterprises supply chain financing model selection [M]. Finance and Communications (integrated) 2011 (8-): 146-147.(In Chinese)

[4] Lu Cai Xia. On corporate debt financing [J]. Friends of Accounting .2009 (10): 66-67.(In Chinese)

[5] Zhou Yuelan. Corporate debt financing risk prevention and control [J]. Chinese business .2010 (12): 146.(In Chinese)

[6] Xiao Kun, Qin Bin. Impact of China's Listed Company's Debt Structure on Financial Governance Efficiency [J]. Economic Management .2011 (2): 110-115.(In Chinese)

[7] Weston, J. F. The Tender Takeover [J] .Mergers and Acquisitions, 1979: $77-81$ 